\title{
Factors Associated with Abortion in Women of Reproductive Age
}

\section{Fatores associados ao aborto em mulheres em idade reprodutiva}

\author{
Ana Paula Vidal dos Santos ${ }^{1}$ Edméia de Almeida Cardoso Coelho ${ }^{2}$ Maria Enoy Neves Gusmão ${ }^{2}$ \\ Diorlene Oliveira da Silva ${ }^{3}$ Patrícia Figueiredo Marques ${ }^{3,4}$ Mariza Silva Almeida ${ }^{2}$
}

\footnotetext{
${ }^{1}$ Professor, Escola Bahiana de Medicina e Saúde Pública, Salvador, BA, Brazil

2 Professor, Nursery School, Universidade Federal da Bahia, Salvador, BA, Brazil

${ }^{3}$ Researcher, Post-Graduation Course, Nursery School, Universidade

Federal da Bahia, Salvador, BA, Brazil

${ }^{4}$ Professor, Universidade Federal do Recôncavo da Bahia, Cruz das Almas, BA, Brazil
}

Address for correspondence Patrícia Figueiredo Marques, MSc, Centro de Ciências da Saúde, Universidade Federal do Recôncavo da Bahia, Avenida Carlos Amaral, 1015-Cajueiro, 44.570-000, Santo Antonio de Jesus, BA, Brazil

(e-mail: pfmenf@ufrb.edu.br; pfmenf@yahoo.com).

Rev Bras Ginecol Obstet 2016;38:273-279.

\begin{abstract}
Keywords

- reproductive health

- abortion

- family health strategy

- nursing

Purpose To verify sociodemographic factors associated with the occurrence of abortion in women of reproductive age, in areas covered by the Family Health Strategy (FHS), a program from the Brazilian Ministry of Health.

Methods A cross-sectional study using household surveys of 350 women aged 15 to 49. The report of abortion was a variable indicator, and sociodemographic aspects were covariables. Prevalence ratio (PR) and respective $95 \%$ confidence intervals were used to estimate the magnitude of the associations.

Results There were associations among age, civil status, race/color, and religion; an increase in the prevalence of lower levels of education, age less than 20 , and student status were protective factors.

Conclusion The association between sociodemographic characteristics and the report of abortion is attributed to the fact that there is a lack at the FHS in the availability of fundamental healthcare services for young women; these findings call for action to guarantee the access to information about contraceptives and guidance to decrease the risk of unplanned pregnancies and abortions.

\section{Resumo}

Objetivo Verificar fatores sociodemográficos associados à ocorrência de aborto em mulheres em idade reprodutiva, em área de cobertura de Estratégia Saúde da Família (ESF).

Métodos Estudo de corte transversal, por inquérito domiciliar com 350 mulheres de 15 a 49 anos de idade. Relato de aborto constituiu variável indicadora e aspectos sociodemográficos covariáveis. Utilizou-se a razão de prevalência (RP) e respectivos intervalos de confiança a 95\% para estimar a magnitude das associações.
\end{abstract}

received

December 15, 2014

accepted

May 3, 2016
DOI http://dx.doi.org/ 10.1055/s-0036-1584940. ISSN 0100-7203.
Copyright $\odot 2016$ by Thieme Publicações License terms Ltda, Rio de Janeiro, Brazil

() (1) $\odot \circledast$ 


\author{
Palvaras-chave \\ - saúde reprodutiva \\ - aborto \\ - estratégia saúde da \\ família \\ - enfermagem
}

\begin{abstract}
Resultados Houve associação entre idade, estado civil, raça/cor e religião. Aumento da prevalência na menor escolaridade e ser menor de 20 anos e estudante constituíram fator de proteção.

Conclusão A associação entre características sociodemográficas e relato de aborto remete a uma atenção à saúde na ESF sem cumprimento dos fundamentos das políticas para mulheres, e suscita ações que garantam às jovens acesso a informações, contraceptivos e a orientações que diminuam os riscos de gravidez não planejada e de abortos.
\end{abstract}

\section{Introduction}

Abortion is considered a major public health problem in Brazil, and is a prominent component of maternal mortality statistics. Due to its magnitude, studies in this field are numerous and constitute a priority in national and international agendas. Although abortion occurs in all social strata, it is prominent among disadvantaged women, and young women are the most vulnerable. ${ }^{1-3}$

The path followed by women seeking abortion is most often long and lonely, corresponding to the increased suffering experienced in maternity wards, when they receive care tainted by prejudice and ill-treatment. ${ }^{4,5}$ In general, women in better socioeconomic conditions resort to safer procedures in private clinics; in contrast, poor women have more difficulty accessing the information and support provided by the public health network, and they also have less bargaining power with their partners in their private lives.

The high rate of hospitalization associated with abortion is a reality when women are subjected unsanitary conditions. In Brazil, it is estimated that 994,465 abortions occur annually, and the annual average coefficient of unsafe abortions is of $17.0 / 1,000$ women of childbearing age, while the ratio of unsafe abortions is of $33.2 / 100$ live births. ${ }^{6}$ The magnitude of the condition is underestimated due to cultural, religious, and legal issues that hinder women from reporting unsafe abortions. ${ }^{7}$ In a study performed on the temporal trend and spatial distribution of unsafe abortions, the State of Bahia had the highest ratio of unsafe abortions per live births in Brazil (53.6/100 live births). ${ }^{6}$

Access to information and contraceptive methods allows a woman to control her own body and make decisions about childbirth. Basic healthcare should guarantee the means that prioritize sexual and reproductive rights for women. The Family Health Strategy (FHS), which mostly works in areas where the population faces social and economic vulnerability, constitutes a resource for facilitating the access of women to means of regulating fertility. Considering the reproductive period as the most demanding phase of the female life cycle because of sexual and reproductive experiences, the objective of this article is to verify the factors associated with the occurrence of abortion in women of reproductive age, in the area of coverage of the FHS in a city in the Northeast of Brazil.

\section{Methods}

This was a cross-sectional study performed in the area of coverage of the FHS. The studied region is considered one of the most disadvantaged in the city of Salvador, the state capital of Bahia, in the Northeast Region of Brazil, ${ }^{8}$ and is marked by difficulties in accessing goods and services due to social, economic, and geographical issues. This study is one of the outcomes of the project "Occurrence of unplanned pregnancies in the coverage area of the Family Health Program in Salvador-BA", funded by the Brazilian National Council for Scientific and Technologic Development (CNPq).

The target population was represented by women aged 15 to 49 years, who were residents in households registered by the FHS. The identification of eligible women was possible by means of the A records of the registry of families living in the area ascribed to a Family Health Unit, obtained by three teams of professionals who worked there. The A record comprises the Basic Health Care Information System, with the registration of women in a database created for the study.

The sample comprised 380 women; during recruitment, 4 of them $(1.1 \%)$ refused to participate in the study. Thus, a response rate of $98.9 \%$ was obtained. A stratified sampling technique by area was used, bounded operationally by the teams of the FHS, making a total of four strata, with allocations proportional to the number of women aged 15 to 49 years in each area. The selection of the interviewees in each household was performed at random and was proportional to the number of women of childbearing age in the area. For this study, women who denied sexual initiation $(n=26)$ were excluded; thus, 350 women were included in the study.

Data collection was performed using structured and semistructured questions with single or multiple answers, whether elicited or spontaneous. The instruments used in the study, "Pregnancy in Adolescence - multicenter study on youth, sexuality and reproduction in Brazil", 10 and the National Demographic and Health Assessment, ${ }^{11}$ were used as the basis for formulating the questions, in addition to other questions elaborated by the researcher, based on the research problem and the goal. A pilot study was performed to evaluate the instrument and make adjustments.

The report of abortion (induced and spontaneous) was used as the outcome variable, and sociodemographic characteristics (age, marital status, race, religion, education, occupational status and family income) were exposure variables. The 
classifications of adolescents of the World Health Organization (WHO) and the Brazilian Ministry of Health were adopted as references. ${ }^{9-11}$

The initial stage of the analysis consisted of the description of the sociodemographic characteristics of women and of the reports of abortion through bivariate distribution frequencies and descriptive measures (mean and standard deviation, SD). Subsequently, the prevalence of the reports of abortion as a measure of occurrence, and the prevalence ratios (PRs) and respective 95\% confidence intervals (CIs) were estimated to verify the magnitude of the associations. The PRs were measured according to the incidence of relative risk (IRR) estimated by Poisson regression, using the robust variance method. ${ }^{8}$ For all analyses, a level of statistical significance of $5 \%(\alpha \leq 0.05)$ was adopted. The database was generated using Microsoft Access v.2002, and the Stata v.12 software was used in the statistical analysis of the results.

The study was approved by the Ethics Committee in Research in Nursing, Opinion No 03/2009. All participants signed a Free and Informed Consent Form (FICF) that guaranteed anonymity, confidentiality of information, the right to withdraw without any prejudice, and permission for access by the researchers to the results of the study.

\section{Results}

Of a total of 350 women included in the study, the majority (51.7\%) was aged $20-34$ years, and $39.4 \%$ were aged 34 years or older ( - Table 1 ). The average age of women who reported abortion was 34.5 years ( $\mathrm{SD}= \pm 8.4$ years); among those who did not report abortion, the average was 29.8 years (SD $= \pm 8.8$ years $){ }^{1}$ Most were married or in a stable union (66.3\%), of mixed race/black (92.9\%), with complete education or education until some point in high school (53.5\%), housewives (50.6\%), and with a family income of 2-3 minimum wages (50.6\%). The prevalence of reports of abortion in the women studied was $31.4 \%$ (-Table 1 ).

The proportional distribution of women that reported abortion according to sociodemographic factors revealed that a large percentage (51.7\%) of the them were aged $\geq 34$ years, with a significant proportional difference between the groups $(p=0.000)$ (-Table $\mathbf{1}$ ).

The groups were homogeneous with regard to marital status, self-reported race and religion ( $\mathrm{p}>0.05$ ). A proportional homogeneity was also verified between the groups regarding level of educationl, family income, and occupational status $(\mathrm{p}>0.05)$ ( - Table $\mathbf{1})$.

With regard to the association between sociodemographic factors and reports of abortion, the prevalence was of $27.1 \%$ among women aged 20 to 34 years, and 1.73 -fold higher in those aged $\geq 34$ years ( $95 \% \mathrm{CI}$ : $1.27-2.35$ ); this was statistically significant when compared with the reference age group (20 to 34 years). In turn, a statistically significant protective effect ( $\mathrm{PR}=0.29 ; 95 \% \mathrm{CI}: 0.09-0.86$ ) was found among younger ( $<20$ years) women ( $\mathbf{- T a b l e ~} \mathbf{2}$ ).

The prevalence of reports of abortion among married/ stable union and divorced/widowed women was of $32.8 \%$ and $33.3 \%$ respectively, and the association was positive in two categories ( $P R=1.16$ and 1.17 respectively), when compared with single women. Although the predominant self-reported race among the women studied was mixed race/black, the prevalence of reports of abortion in this group was of $28.8 \%$, while among indigenous people it was of $50 \%$. There was a positive association $(P R=1.50)$ for reports of abortion in this group when compared with the category self-identified as white, with a prevalence of 5.7\%; however, this was statistically significant. The predominant religion among the women studied was Catholicism, followed by Evangelical Protestantism (-Table 1). A positive association was found for the reports of abortion for both religions $(\mathrm{PR}=1.36$; 95\% CI: $0.87-2.12$ and $\mathrm{PR}=1.19$ 95\% CI: 0.751.89 respectively), but without statistical significance.

There was an inverse association between the prevalence of reports of abortion and education: the lower the level of education (literate/incomplete elementary school), the higher the prevalence of reports of abortion among women (38.5\%). Women with a lower level of education reported abortion 1.30-fold more often (95\% CI: 0.72-2.38), when compared with those with a higher level of education, but this result was not statistically significant (-Table 2 ).

As for occupational status, a predominance of housewives was observed, followed by women who work for a living and students. The first two groups presented a null association (PR $=1.095 \% \mathrm{CI}: 0.68-1.41)$. However, being a student was a statistically significant protective factor for the report of abortion ( $\mathrm{PR}=0.37 ; 95 \% \mathrm{CI}$ : 0.14-0.94) when compared with women who work for a living. Regarding family income, there was a predominance of families with an income of 2-3 minimum wages (50.6\%); the prevalence in this group was of $34.9 \%$, and the association with reports of abortion was negative $(P R=0.97)$ and without statistical significance (95\% CI: 0.52-1.81) when compared with the reference group (with an income of 4-5 minimum wages) ( - Table 2 ).

\section{Discussion}

Published data confirm the prevalence of abortion among socially disadvantaged women, who more frequently experience unplanned pregnancies and a higher rate of abortion. A study performed in the city of São Paulo confirms this reality, with an increase in the rate of abortions with age being more prevalent among women 35 years or older, that is, at the end of reproductive age. ${ }^{12}$ Stable unions predominate in this age group, with greater regularity in sexual activity and a higher exposure to pregnancy, similar to the findings of our study.

In the health district investigated in Salvador-BA, an association between sociodemographic factors and the report of abortion was verified. Abortion was more frequent among women who were black, $\geq 34$ years, in a married/stable union, Catholic or Evangelical Protestant, with complete or incomplete high school education, housewives, and with a family income of 2-3 minimum wages. Women 34 years or older showed an association with reports of abortion compared with other age ranges. 
Table 1 Proportional distribution of reports of abortion, according to sociodemographic factors in women enrolled in the Family Health Strategy $\left(n=350^{*}\right)$

\begin{tabular}{|c|c|c|c|c|c|c|c|}
\hline \multirow[t]{3}{*}{ Sociodemographic factors } & & & \multicolumn{4}{|c|}{ Report of abortion } & \multirow[t]{3}{*}{$p^{\mathrm{b}}$} \\
\hline & \multicolumn{2}{|l|}{ Total } & \multicolumn{2}{|c|}{$\begin{array}{l}\text { No } \\
240(68.6)\end{array}$} & \multicolumn{2}{|c|}{$\begin{array}{l}\text { Yes } \\
110(31.4)\end{array}$} & \\
\hline & $N$ & (\%) & $N$ & (\%) & $\mathrm{N}$ & (\%) & \\
\hline \multicolumn{8}{|l|}{ Age (years) } \\
\hline$<20$ & 31 & 8.9 & 28 & 11.7 & 3 & 2.7 & \multirow[t]{3}{*}{0.000} \\
\hline $20-34$ & 181 & 51.7 & 132 & 55.0 & 49 & 44.6 & \\
\hline$\geq 34$ & 138 & 39.4 & 80 & 33.3 & 58 & 52.7 & \\
\hline \multicolumn{8}{|l|}{ Marital status } \\
\hline Single & 109 & 31.1 & 78 & 32.5 & 31 & 28.2 & \multirow[t]{3}{*}{0.711} \\
\hline Married/stable union & 232 & 66.3 & 156 & 65.0 & 76 & 69.1 & \\
\hline Divorced/widowed & 9 & 2.6 & 6 & 2.5 & 3 & 2.7 & \\
\hline \multicolumn{8}{|l|}{ Color (self-reported) $(n=340)$} \\
\hline White & 22 & 6.5 & 16 & 6.8 & 6 & 5.7 & \multirow[t]{3}{*}{0.747} \\
\hline Brown/black & 316 & 92.9 & 218 & 92.8 & 98 & 93.3 & \\
\hline Indigenous & 2 & 0.6 & 1 & 0.4 & 1 & 1.0 & \\
\hline \multicolumn{8}{|l|}{ Religion } \\
\hline Without religion & 66 & 18.9 & 47 & 19.6 & 19 & 17.3 & \multirow[t]{4}{*}{0.743} \\
\hline Catholic & 147 & 42.0 & 98 & 40.8 & 49 & 44.5 & \\
\hline Evangelical protestant & 133 & 38.0 & 93 & 38.8 & 40 & 36.4 & \\
\hline Other & 4 & 1.1 & 2 & 0.8 & 2 & 1.8 & \\
\hline \multicolumn{8}{|l|}{ Schooling $(n=346)$} \\
\hline College complete and incomplete & 135 & 39.0 & 101 & 42.8 & 34 & 30.9 & \multirow[t]{3}{*}{0.093} \\
\hline High School education complete and incomplete & 185 & 53.5 & 119 & 50.4 & 66 & 60.0 & \\
\hline Literate/incomplete elementary & 26 & 7.5 & 16 & 6.8 & 10 & 9.1 & \\
\hline \multicolumn{8}{|l|}{ Employment status } \\
\hline Remunerated activity & 90 & 25.7 & 62 & 25.8 & 28 & 25.4 & \multirow[t]{4}{*}{0.174} \\
\hline Unemployed & 54 & 15.4 & 36 & 15.0 & 18 & 16.4 & \\
\hline Housewife & 177 & 50.6 & 117 & 48.8 & 60 & 54.5 & \\
\hline Student & 29 & 8.3 & 25 & 10.4 & 4 & 3.6 & \\
\hline \multicolumn{8}{|l|}{ Family income (in MW) ${ }^{\mathrm{a}}(n=346)$} \\
\hline$\leq 1$ & 150 & 43.4 & 110 & 46.2 & 40 & 37.0 & \multirow[t]{3}{*}{0.284} \\
\hline $2-3$ & 175 & 50.6 & 114 & 47.9 & 61 & 56.5 & \\
\hline $4-5$ & 21 & 6.1 & 14 & 5.8 & 7 & 6.5 & \\
\hline
\end{tabular}

Abbreviations: MW, minimum wage; $\mathrm{n}$, number.

Notes: mean age $1 / 431.38 .9$ years; ${ }^{a} \mathrm{MW}$ : minimum reference wage $\mathrm{R} \$ 465.00$; women without sexual initiation were excluded;

${ }^{\mathrm{b}}$ Chi-squared, and Fisher's exact tests.

With regard to abortion in adolescents, those from the low-income population group are vulnerable to unplanned pregnancies and a possible decision for abortion, especially due to their limited access to information, contraceptives, and clinical and educational monitoring because of policy limitations on reproductive healthcare. $^{13}$ This assertion is reinforced by the findings of this study, even though age below 20 years was a protective factor.
One should also consider that induced abortion is a difficult decision for women. This subject is tainted by prejudice, moral values, and punitive legislation, which inhibits women from exercising their reproductive rights, and leads them to avoid reporting. ${ }^{14,15}$

In a cross-sectional study on marital status and reports of abortion conducted in the city of São Paulo in 2012, it was observed that single women, regardless of age, were more likely to resort to the voluntary interruption of pregnancy. 
Table 2 Association between sociodemographic factors and reports of abortion in women enrolled in the Family Health Strategy $\left(n=350^{*}\right)$

\begin{tabular}{|c|c|c|}
\hline \multirow[t]{2}{*}{ Sociodemographic factors } & \multicolumn{2}{|c|}{ Reporting of abortion } \\
\hline & Prevalence (\%) & $\mathrm{PR}^{\mathrm{b}}(95 \% \mathrm{Cl})$ \\
\hline \multicolumn{3}{|l|}{ Age group (years) } \\
\hline$<20$ & 9.7 & $0.29(0.09-0.86)$ \\
\hline $20-34$ & 27.1 & $1.0^{\mathrm{c}}$ \\
\hline$\geq 34$ & 42.0 & $1.73(1.27-2.36)$ \\
\hline \multicolumn{3}{|l|}{ Marital status } \\
\hline Single & 28.4 & $1.0^{c}$ \\
\hline Married/stable union & 32.8 & $1.16(0.82-1.66)$ \\
\hline Divorced/widowed & 33.3 & $1.17(0.46-2.96)$ \\
\hline \multicolumn{3}{|l|}{ Color (self-reported) $(n=340)$} \\
\hline White & 5.7 & $1.0^{c}$ \\
\hline Brown/black & 28.8 & $1.04(0.52-2.07)$ \\
\hline Indigenous & 50.0 & $1.50(0.27-7.96)$ \\
\hline \multicolumn{3}{|l|}{ Religion } \\
\hline Without religion & 28.8 & $1.0^{c}$ \\
\hline Catholic & 33.3 & $1.36(0.87-2.12)$ \\
\hline Evangelical protestant & 30.1 & $1.19(0.75-1.89)$ \\
\hline Other & 50.0 & $1.89(0.76-4.67)$ \\
\hline \multicolumn{3}{|l|}{ Schooling $(n=346)$} \\
\hline College complete and incomplete & 25.2 & $1.0^{\mathrm{C}}$ \\
\hline Complete and incomplete high school education & 35.7 & $1.25(0.87-1.80)$ \\
\hline Literate/incomplete elementary school & 38.5 & $1.30(0.72-2.38)$ \\
\hline \multicolumn{3}{|l|}{ Employment status } \\
\hline Remunerated Activity & 31.1 & $1.0^{\mathrm{C}}$ \\
\hline Unemployed & 33.3 & $1.00(0.60-1.62)$ \\
\hline Housewife & 33.9 & $1.00(0.68-1.41)$ \\
\hline Student & 13.8 & $0.37(0.14-0.94)$ \\
\hline \multicolumn{3}{|l|}{ Family income (in MW) ${ }^{\mathrm{a}}(n=346)$} \\
\hline$\leq 1$ & 26.7 & $0.70(0.36-1.34)$ \\
\hline $2-3$ & 34.9 & $0.97(0.52-1.81)$ \\
\hline $4-5$ & 33.3 & $1.0^{\mathrm{C}}$ \\
\hline
\end{tabular}

Abbreviations: $\mathrm{Cl}$, confidence interval, MW, minimum wage; $\mathrm{n}$, number; PR, prevalence ratio.

Notes: ${ }^{\mathrm{a}} \mathrm{MW}$ : minimum reference wage $\mathrm{R} \$ 465.00$; ${ }^{\mathrm{b}}$ Adjusted by age of sexual initiation; ${ }^{\mathrm{c}}$ reference category.

This is explained by the irregular use of contraceptive methods, either because of lack of effectiveness or lack of access. ${ }^{16}$ In contrast, women in stable relationships or who were divorced/widowed presented a positive association, reporting more pregnancy interruptions in this study.

Another sociodemographic aspect assessed was race/color, although there was no association with reports of abortion. Given that the population of this study was mostly black, this result is in agreement with another study conducted in Brazil, ${ }^{17}$ in which there was also no association between reports of abortion and this variable. However, black women in unfavorable socioeconomic conditions and with less education are the most vulnerable, and contribute to the profile of maternal deaths and complications per number of abortions. ${ }^{8,18}$

The higher percentage of reports of abortion among Catholic and Evangelical Protestant women with a positive association for both allows us to affirm that the circumstances in which pregnancies occur overlap with religious dogmas. This was unlike the results of a prospective and case-controlled study conducted with women living in the periphery of São Paulo, in which there was no report of induced abortion in the group of Evangelical women. ${ }^{19}$ However, as we did not verify the religion at the time of 
abortion, this information constitutes a limitation of our study.

Similar to the findings of our study, women with a higher level of education and higher family income presented a higher prevalence of abortion in some studies. ${ }^{10,15,19}$ However, it is clear that such women, when facing unplanned pregnancies, undergo safer procedures than women who do not have the same social advantages. ${ }^{19}$ Moreover, given that the prevailing income was low in our study, unsafe conditions increase vulnerability to illness and death.

Being a student was a protective factor for abortion in the present study, recognizing that the higher the schooling, the lower the chances of unplanned pregnancies and decision for abortion. It is noteworthy, however, that access to information does not guarantee self-protective behavior, because reproductive self-management requires discussion between partners, self-confidence and social support, which are seldom present during sexual initiation in adolescence. ${ }^{20,21}$

While adult women have a more stable psychological structure and more durable intimate relationships, and are more able to manage their sexuality, adolescents experience a sense of discovery and freedom, with the need to experience instant pleasure. 22

The results of this survey are in agreement with those of other studies, showing that in an institutionalized healthcare practice, misinformation, difficulties of access, and irregularity in the use of contraceptive methods, along with the discontinuation of services or personal impediments to access are part of a woman's experience, resulting in unplanned pregnancies. ${ }^{12,23,24}$

A significant challenge is the difficulty of accessing reliable data, including those generated from questionnaires with direct questions, because many women fail to report induced abortion. This fact limits the calculation of the magnitude of abortion in Brazil, ${ }^{6}$ because many women report that abortions were spontaneous; this lack of reports of induced abortions is the result of a series of issues that involve legal, religious, and cultural aspects. As a result, the data indicate the need for further studies about the possibility of indirect obstetric issues, such as preexisting chronic diseases or sickle cell anemia, or direct issues, such as cervical incompetence.

This study has some limitations. First, because this was a cross-sectional study, the data are based on a single time period. The second is the nature of the events studied and the veracity of the information provided by the interviewees, mainly about events that have occurred in the past, which are subject to judgment. In this sense, a face-to-face interview in a quiet place may have minimized this issue, while providing results consistent with those of other studies.

\section{Conclusions}

This study assessed the association between sociodemographic factors and reports of abortion. There was a positive association between the ages of 34 years or older and reports of abortion, while an age lower than 20 years had a protective effect; among married women/stable union and divorced/ widows in comparison with single women; brown skin color/ black when compared with the reference white group; and between Catholic and Evangelical Protestant religions. The survey indicated that the lower the educational level, the higher the prevalence of reports of abortion among women, but this was not statistically significant; there was no association between the occupational status and reports of abortion, but being a student was a protective factor; regarding family income, the association was negative and without statistical significance.

Abortion is a troubling event, given its important relationship with maternal morbidity and mortality, especially in the city of Salvador. The relationship between sociodemographic characteristics and reports of abortion indicates a compromised public health commitment built on a model marked by lack of investment and without the promised reorganization of basic care through the FHS. Such findings in the area of coverage of the FHS indicate the need for combined action by the health and education sectors, to ensure access to information for young women, with the goal of reducing the risk of unplanned pregnancies and abortions.

The results of this study condemn an inefficient health system that fails in the implementation of public policies for women of all ages. Thus, access to information compatible with life context, and to contraceptives and clinical monitoring, supported by educational actions, has not been available. Therefore, policies that are supportive of women have not been implemented; there is still much to do to strengthen primary care in the framework of women's health and respect for sexual and reproductive rights.

\section{Acknowledgments}

To CNPq, for the research funding (Edital 57/2008); to the teams of the FHS for supporting the study and facilitating access to participants.

\section{References}

1 Diniz NMF, Gesteira SMA, Lopes RLM, Santos Mota R, Pérez BAG, Gomes NP. Voluntary abortion and domestic violence among women attended at a public maternity hospital of Salvador-BA. Rev Bras Enferm 2011;64(6):1010-1015

2 Mortari CLH, Martini JG, Vargas MA. [Nurses' representations regarding the care of women experiencing unsafe abortion]. Rev Esc Enferm USP 2012;46(4):914-921

3 Sell SE, Santos EKA, Velho MB, Erdmann AL, Rodriguez MdeJ. Reasons and meanings attributed by women who experienced induced abortion: an integrative review. Rev Esc Enferm USP 2015;49(3):495-501

4 Schwandt HM, Creanga AA, Adanu RM, Danso KA, Agbenyega T, Hindin MJ. Pathways to unsafe abortion in Ghana: the role of male partners, women and health care providers. Contraception 2013; 88(4):509-517

5 Kapp N, Whyte P, Tang J, Jackson E, Brahmi D. A review of evidence for safe abortion care. Contraception 2013;88(3):350-363

6 Martins-Melo FR, Lima MdaS, Alencar CH, et al. Temporal trends and spatial distribution of unsafe abortion in Brazil, 1996-2012. Rev Saude Publica 2014;48(3):508-520 
7 Rocha BNGA, Uchoa SAC. [Evaluation of humanized care in abortion: an evaluability study]. Physis 2013;23(1):109-127 Portuguese

8 Coelho EAC, Andrade MLS, Vitoriano LVT, et al. Associação entre gravidez não planejada e o contexto socioeconômico de mulheres em área da Estratégia Saúde da Família. Acta Paul Enferm. 2012; 25(3):415-422

9 Heilborn ML. [For a positive agenda of sexual rights of adolescents]. Psicol Clin 2012;24(1):57-68 Portuguese

10 Pilecco FB, Knauth DR, Vigo Á. [Sexual coercion and abortion: a context of vulnerability among young women]. Cad Saude Publica 2011;27(3):427-439 Portuguese

11 Rocha BMP, Martins AIC, Pereira MMN, Santos PIM, Mestre RES. Perfil de saúde dos adolescentes de uma cidade no Algarve. Rev Enf Ref 2013;serIII(9):85-93

12 Souza MG, Fusco CLB, Andreoni SA, de Souza e Silva R. Prevalence and sociodemographic characteristics of women with induced abortion in a population sample of São Paulo, Brazil. Rev Bras Epidemiol 2014;17(2):297-312

13 Nunes Md, Madeiro A, Diniz D. Histories of induced abortion among adolescents from Teresina in the State of Piauí, Brazil. Cien Saude Colet 2013;18(8):2311-2318

14 Freire N. Aborto seguro: um direito das mulheres? Cienc Cult 2012;64(2):31-32

15 Andreoni S, Silva RS, Drezett J. Quem está mais propensa a recorrer ao aborto provocado diante de uma gravidez indesejada? Estudo com mulheres em idade fértil residentes em três regiões da cidade de São Paulo, Brasil. Reprod Clim. 2012;27(2):41-46
16 de Souza e Silva R, Andreoni S. Induced abortion: a comparison between married and single women residing in the city of São Paulo in 2008. Cien Saude Colet 2012;17(7):1725-1733

17 Cecatti JG, Guerra GVQL, Sousa MH, Menezes GMS. [Abortion in Brazil: a demographic approach]. Rev Bras Ginecol Obstet 2010; 32(3):105-111 Portuguese

18 Diniz D, Medeiros M. [Itineraries and methods of illegal abortion in five Brazilian state capitals]. Cien Saude Colet 2012;17(7): 1671-1681 Portuguese

19 Borsari CMG, Nomura RMY, Benute GRG, Lucia MCS, Francisco RPV, Zugaib M. [Abortion in women living in the outskirts of São Paulo: experience and socioeconomic aspects]. Rev Bras Ginecol Obstet 2013;35(1):27-32 Portuguese

20 Correia DS, Cavalcante JC, do Egito ES, Maia EMC. [Practice of abortion among teenagers: a study in ten schools of Maceió (AL, Brazil)]. Cien Saude Colet 2011;16(5):2469-2476 Portuguese

21 Silva LVM, Coelho EAC. [Sexual experiences of adolescent mothers, vulnerability and double protection]. Rev Baiana Enferm 2011;25(2):133-144 Portuguese

22 Sousa JJ. Circunstâncias da ocorrência de gravidez não planejada em mulheres adultas [dissertação]. Salvador: Universidade Federal da Bahia; 2011

23 Anjos KF, Santos VC, Souzas R, Eugenio BG. Aborto e saúde pública no Brasil: reflexões sob a perspectiva dos direitos humanos. Saúde Debate 2013;37(98):504-515

24 Brito RC, Ferreira ALCG, Ferreira ECG, Bú SMA, Souza AI. Sociodemographic and reproductive profile of women with abortion complications in hospital in Recife. Esc Anna Nery 2013;17(3):491-495 